\title{
AN ANALYSIS OF GRAMMATICAL ERRORS IN STUDENTS' WRITING DESCRIPTIVE TEXT
}

\author{
Sari Sadiah ${ }^{1}$, Seli Ade Royani ${ }^{2}$ \\ ${ }^{1}$ IKIP Siliwangi \\ ${ }^{2}$ IKIP Siliwangi \\ ${ }^{1}$ sarisadiah@gmail.com, ${ }^{2}$ shelyaderoyani@yahoo.com
}

\begin{abstract}
Writing is considered as the most complicated skill to be mastered required not only great vocabularies but also grammar, as Harmer (2004:31) cited in (Wati \& Nursyaebah, 2017) states that, when writing, learners often have more time to think than they do in spoken activities. Therefore, they can stimulate their brain,even consult dictionaries, grammar books or other reference material to help them . $\mathrm{He}$ believes that grammar is really important in writing that is why he suggested to consult grammar books to make the writing grammatically correct. Therefore, the basic objective of this study is to analyze students' grammatical errors in writing especially in descriptive text. In addition, (Wati \& Nursyaebah, 2017) there are six classifications of grammatical error; those are verb agreement (Leech, 1985), capitalization (Oshima, 1988) usage, sentence pattern (Ross, 1975) pronoun and spelling (Brooks, 1964). The data were analyzed based on the error analysis's of students in writing. In the research finding it showed that students mostly did error in verb agreement $41 \%$ that caused by using incorrect fromsimple present, followed by pronoun $18 \%$, usage $15 \%$, sentence pattern $12 \%$, spelling $9 \%$, and capitalization error 5\%. From the result finding, it is necessary or students learn more about English grammar and it is suggested for teacher to re-teaching about verb agreement and pronoun as the most failure which students mostly did in their writing.
\end{abstract}

Keywords: Grammatical Errors, Writing, Descriptive Text

\section{INTRODUCTION}

Writing and grammar can not be separated each other because grammatical rules are one of aspects that the learners should consider before they write something. Grammar mastery is very important in writing skill, it can help the students to produce good sentences. According to Swan (1998: 19) cited in (Khairunisa, A., Nadrun, 2018), "grammar is the rule that says how words are changed to show different meaning, and they combine into sentences". It means grammar is a way in forming a different meaning of words which use to contruct a sentence in writing. Writing requires hard thinking for formulating ideas into a word, word into sentence, and sentence into paragraph at the same time with good grammar.It is in line with what had been stated by Caroline (2003:4, cited in Argawati \& Suryani, 2018) that writing is producing something in written form then people can read, perform and use it. Therefore, in composing paragraph in writing activity take a lot time, as explained by Nunan (1991:88, cited in Parmawati, 2016) that writing skill can develop rapidly when students' concerns and interests are acknowledged, when they are given numerous opportunities to write. In addition, Harmer (2004:3, cited in Wati \& Nursyaebah, 2017) argue, writing is often not time-bound in the way conversation is. They can go through what they know in their minds, and even consult dictionaries, grammar books or order reference material to help them. Itcan be cloncluded written is product of writing that people can read, perform and use it, and to produced it they can use many references material to help them such as dictionaries and grammar books. 


\section{Volume 2, No. 6, November 2019 pp 764-770

The knowledge of grammatical rules is very important in expressing what the learners want to say and interpret correctly. Based on Strumpf \& Douglash (2004, cited in Haryudin, A., \& Argawati, 2018) argue "we study grammar then we may speak and write in a clearer and more effective manner". It indicates that grammar plays a significant role in communication since it show how language is used, Ismail (2010, cited in Apsari, 2018). Therefore, the students can convey their message clearly, precisely, and easy to be understood by other when they mastery good grammar.

One of the texts that close to the learners' life are descriptive text because it is you are writing about what a person, place, or thing is like stated by Blaylock (2006:1) cited in (Exdriko, Tavriyanti, \& Refnita, 2011). A descriptive text usually has two main sections: first identification it is about how to introduction of a person, place, animal, or object will be described. And second it is about description of something such as animal, things, place or person by describing its feature, forms, colors, or anything related to what the writer describe. Descriptive text also has characteristic or language features such as adjectives and compound adjective dominant to used and using the simple present tense.

Learners can explore and describe about their friend related about their characteristic, deed and something special from them. In fact, most of them consider writing is complicated because they have to use grammatical ruler and proper lexical. Therefore, the writer decided to choose descriptive text as students' activity this study. There are six elements typical errors, such as: verb agreement it is about matching in number and person of subject, capitalization is the first letter of a word, usage is about articles, plural-singular form, and proposition, sentence patternis the basic sentence pattern of English is subject+verb+object/complement, pronoun is about a pronoun represents a person, place, thing, or idea without naming it and the last is spelling it is about relatively minor importance as far as reading is concerned.(Brooks, 1964:168;Leech andSvartvik, 1984:153; Oshima and Hogue, 1988:7; Ross and Doty, 1975:5).

This research would like to know what kinds of grammatical errors that the learners made in writing descriptive text.

\section{METHOD}

The research employed qualitative descriptive methode as the research methodology. This is because the writer analyzed the data descriptively and the presentation of the result was in form of explanation of words which would be supported by data presented in the form of table. Suryana (2010) argues that descriptive research is focused to make description sistematically and accuratelly based on fact about a certain object. The goal of descriptive research is to describe a phenomenon and its characteristics, this research is more concerned with what rather than how or why something has happened. Therefore, observation and survey tools are often used to gather data (Gall \& Borg, 2007, cited in Nassaji, 2015). In such research, the data may be collected qualitatively, but it is often analyzed quantitavely, using frequencies, percentages, averages, or other statistical analyses to determine relationship. Qualitative research, however, is more holistic and often involves a rich collection of data from various sources to gain a deeper understanding of individual participants, including their opinions, perspectives, and attitudes.

In collecting data the writer only used writing assignment descriptive text in my friend theme of seventh grade students in SMP Negeri 3 Cimahi in academic years 2018-2019 consist 23 students, to analyze grammatical errors. The data are analyzed by using grammatical error or to the process of determining incidence, nature, cause and consequences of unsuccessful language 
(James, 1998:1; Brooks, 1964:168; Leech and Svartvik, 1984:153; Oshima and Hogue, 1988:7; Ross and Doty, 1975:5)

\section{RESULTS AND DISCUSSION}

\section{Results}

The percentage of recapitulation of students' errors are converted into chart. The chart covers the highest until rank as follows:

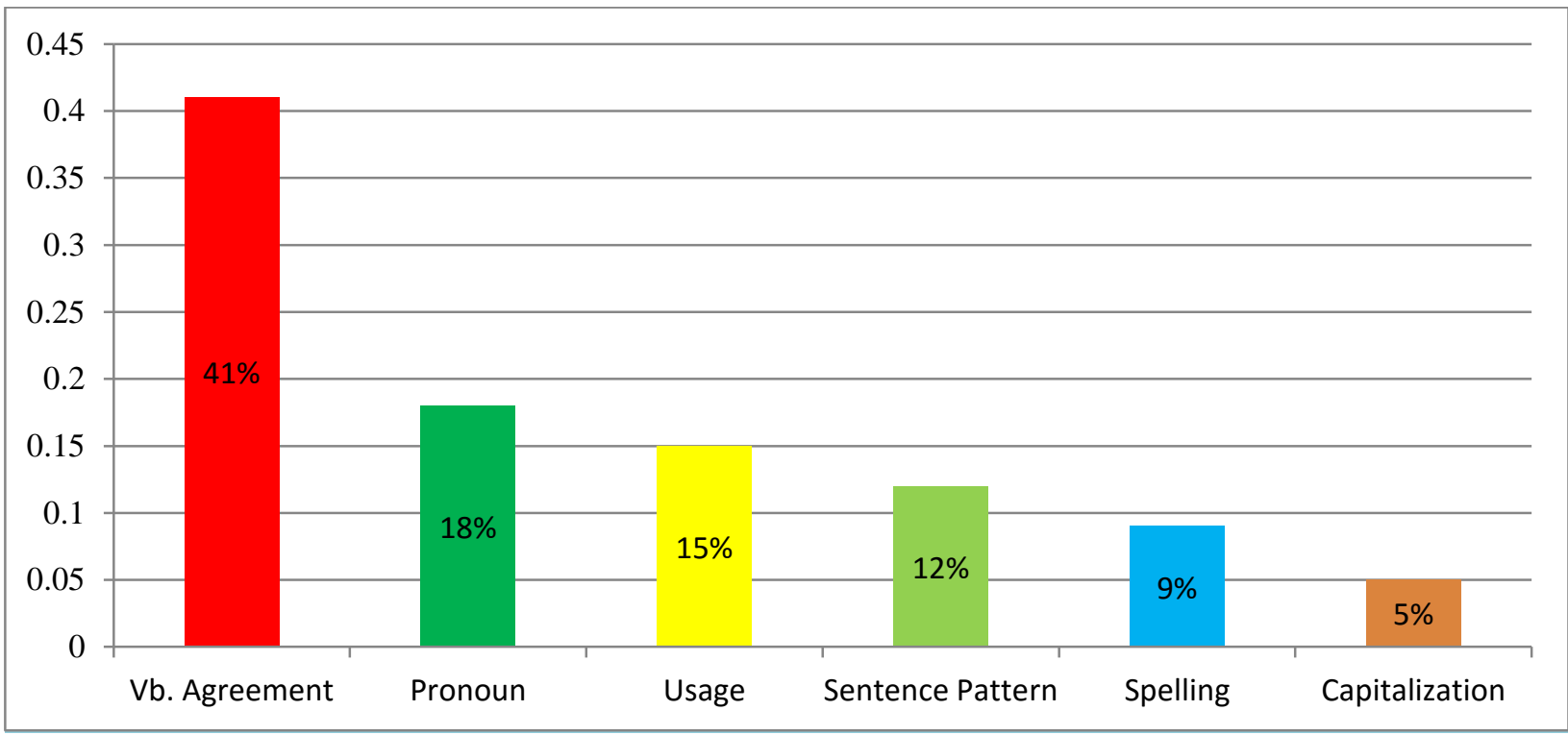

The chart explains the kinds of errors that students made. The writer would like to elaborate the result of the chart above from the highest error number until the lowest rank.Most of students made error in verb agreement, there are 43 or $41 \%$. The writers assume that the students did errors in correlation between subject and verb. The errors in pronoun are 19 or $18 \%$, usages are 16 or $15 \%$, sentence pattern are 13 or $12 \%$, spelling error are 9 or $9 \%$, and capitalization error are 5 or $5 \%$. The data from the students collected, then analyzed the errors by using classify the error, and quantify the error. These stept are proposed by Gass and Selinker (1994:66).

Moreover, to know the result of students' grammatical errors, the writer made the table of students' grammatical errors as follows:

Table 1. The Recapitulation of Students' Grammatical Error

\begin{tabular}{cccccccc}
\hline \multirow{2}{*}{ Student } & \multicolumn{7}{c}{ Types of Grammatical Errors } \\
\cline { 2 - 8 } & $\begin{array}{c}\text { Vb. } \\
\text { Agreement }\end{array}$ & Capitalization & Usage & $\begin{array}{c}\text { Sentence } \\
\text { Pattern }\end{array}$ & Pronoun & Spelling & Total \\
\hline 1 & 0 & 1 & 0 & 0 & 0 & 1 & 2 \\
\hline 2 & 0 & 0 & 1 & 1 & 0 & 1 & 3 \\
\hline 3 & 2 & 0 & 1 & 0 & 0 & 0 & 3 \\
\hline 4 & 1 & 0 & 1 & 0 & 0 & 0 & 2 \\
\hline 5 & 1 & 0 & 0 & 0 & 6 & 0 & 7 \\
\hline 6 & 3 & 0 & 1 & 1 & 0 & 0 & 5 \\
\hline 7 & 2 & 0 & 1 & 0 & 0 & 0 & 3 \\
\hline 8 & 2 & 0 & 2 & 2 & 0 & 0 & 6 \\
\hline 9 & 4 & 0 & 1 & 0 & 0 & 0 & 5
\end{tabular}




\begin{tabular}{cccccccc}
\hline 10 & 3 & 0 & 3 & 0 & 0 & 0 & 6 \\
\hline 11 & 5 & 0 & 2 & 1 & 0 & 1 & 9 \\
\hline 12 & 4 & 0 & 1 & 1 & 0 & 0 & 6 \\
\hline 13 & 2 & 0 & 0 & 0 & 1 & 1 & 4 \\
\hline 14 & 0 & 0 & 0 & 1 & 1 & 2 & 4 \\
\hline 15 & 1 & 0 & 0 & 0 & 2 & 0 & 3 \\
\hline 16 & 2 & 0 & 0 & 1 & 2 & 0 & 5 \\
\hline 17 & 4 & 0 & 0 & 1 & 1 & 0 & 6 \\
\hline 18 & 0 & 0 & 0 & 1 & 1 & 0 & 2 \\
\hline 19 & 1 & 0 & 0 & 0 & 2 & 0 & 3 \\
\hline 20 & 1 & 1 & 0 & 1 & 2 & 1 & 6 \\
\hline 21 & 1 & 0 & 0 & 1 & 0 & 0 & 2 \\
\hline 22 & 4 & 0 & 1 & 0 & 1 & 0 & 6 \\
\hline 23 & 0 & 3 & 1 & 1 & 0 & 2 & 7 \\
\hline Total & 43 & 5 & 16 & 13 & 19 & 9 & 105 \\
\hline $\begin{array}{c}\text { Percentage of } \\
\text { error }\end{array}$ & $41 \%$ & $5 \%$ & $15 \%$ & $12 \%$ & $18 \%$ & $9 \%$ & $100 \%$
\end{tabular}

\section{Verb Agreement}

Based on the results here are the errors $41 \%$ in verb agreement that made by students, students number 3-13, 15-17, and 19-23. Examples :

Table 2. Verb Agreement

Incorrect sentence

1. Diana have a black hair and long.

2. She like hot chocolate and pizza.

3. Her favorite color is white and yellow.

4. He have same hobby as me.
Correct sentence

1. Diana has black hair and long.

2. She likes hot chocolate and pizza.

3.Herfavoritecolors are white andyellow.

4.He has same hobby as me.

In these sentences, the students still confused about plural or singular subject related with the verb. It is should be he/she/it used has not have. She/he/it add verb + s/es/ies.

\section{Capitalization}

Some students made errors in capitalizing some letters $5 \%$, students number 1,20 , and 23 . Examples :

Table 3. Capitalization

Incorrect sentence

1.My name is febby.

2.My name is OKTA.

3.kaka is my friend.
Correct sentence

1.My name is Febby.

2.My name is Okta.

3.Kaka is my friend

Students should be used capitalization to the first letters of name a person. 
3. The third classification of grammatical error was usage, usage areas are article and preposition. The writer found $15 \%$ that students number 2-4,6-12, 22-23 used inappropriate preposition and article in the sentences :

Table 4. The Third Classification of Grammatical Error Was Usage

\begin{tabular}{ll}
\hline \multicolumn{1}{c}{ Incorrect sentence } & \multicolumn{1}{c}{ Correct sentence } \\
\hline 1.Her mother is an house wife. & 1.Her mother is a house wife. \\
2.She was born 8 April 2006. & 2.She was born on April $8^{\text {th }}, 2006$. \\
3.The date of birth of 30 May 2006. & 3.The date of birth on May $30^{\text {th }}, 2006$. \\
\hline
\end{tabular}

The students still confuse used article and how to write the date on sentence.

\section{Sentence pattern}

And the fourth error $12 \%$ that writer found in students number 2,6,8,11-12,20-21, and 23 sentences was sentence pattern, example :

Table 5. Sentence Pattern

\begin{tabular}{ll}
\hline \multicolumn{1}{c}{ Incorrect sentence } & \multicolumn{1}{c}{ Correct sentence } \\
\hline 1.Revalina hobby draw. & 1.Revalina's hobby is draw. \\
2.Hi, my name Rizkita. & 2.Hi, my name is Rizkita. \\
3.His weight $32 \mathrm{~kg}$. & 3.His weight is $32 \mathrm{~kg}$. \\
\end{tabular}

Students forget used to be after subject and did not put apostrophe('s) in the sentence.

\section{Pronoun}

The fifth error was pronoun, the writer found $19 \%$ that many students number 5,13-20, and 22 did not use pronoun, examples :

Table 6. Pronoun

\begin{tabular}{ll}
\hline \multicolumn{1}{c}{ Incorrect sentence } & \multicolumn{1}{c}{ Correct sentence } \\
\hline 1.I have a friend, this name is Zaky. & 1.I have a friend, his name is Zaky. \\
2.She age is 13 years old. & 2.Her age is 13 years old. \\
3.He hobby is plays game. & 3.His hobby is plays game. \\
4.She tall is 191 cm. & 4.Her tall is 191 cm. \\
5.She name is Rizki Putri S. & 5.Her name is Rizkita Putri S. \\
& \\
\hline
\end{tabular}

Many students still confuse about pronouns.

\section{Spelling}


The last but not least error was spelling, as Brooks (1964:168, cited in Wati \& Nursyaebah, 2017) noted that "Spelling is of relatively minor importance as far as reading is concerned; it becomes a major factor in the productive skill writing". Therefore, it is important to spell the words correctly. Errors 9\% made by students number 1-2, 11,13-14, 20, and 23. Examples:

Table 7. Spelling

\begin{tabular}{ll}
\hline \multicolumn{1}{c}{ Incorrect sentence } & \multicolumn{1}{c}{ Correct sentence } \\
\hline 1.She likes coklate. & 1.She likes chocolate. \\
2.I learned how to play game from hes. & 2.I learned how to play game from him. \\
3.Hi is thin. & 3.He is thin. \\
4.Sometame he is funny & 4.Sometimes he is funny. \\
&
\end{tabular}

It can be concluded that the students can not write the words correctly. Therefore, it can be found many mistakes spelling. It means that the teacher plays an important role in teaching to make students write correctly.

\section{CONCLUSION}

Based on the description of the data above, it can be concluded that from six classification of grammatical errors, those are verb agreement, capitalization, usage, sentence pattern, pronoun and spelling, the writer found that the most grammatical errors made students was verb agreement, with total errors are 43 or $41 \%$ because of that, we as teacher should pay more attention to students grammar especially in subject and verb so that the students could minimalize their errors in their writing.

\section{ACKNOWLEDGMENTS}

First, for students as one of the learning resources to know how to write descriptive text with appropriate grammar and as a correction material for writing students. Second as a references for educate in developing students' abilities, especially students' writing skills, to provide knowledge on how to efectivelly apply grammar to students so that students remain confident and enthusiastic about learning.

\section{REFERENCES}

Aninda Khairunisa 1 ; Nadrun 2 ; Rachmania 3. The Correlation Between Students' Grammar Mastery And Writing Skill Aninda, Vol 6, No, 1-11. 11

Apsari, Y. (2018). Snowball Throwing In Teaching Grammar. Lingual, 10(1), 52-59.

Argawati, N. O., \& Suryani, L. (2017). Teaching Writing Using Think-Pair-Share Viewed From Students'level Of Risk-Taking. English Review, 6(1).

Exdriko, Y., Tavriyanti, L., \& Refnita, L. (2011). The Teaching Of Writing A Descriptive Text Using Clustering Technique For Bung Hatta University Students, 1-10.

Haryudin, A., \& Argawati, N. O. (2018). Lesson Study To Improve Student English Grammar Mastery Using Jigsaw Technique To The Third Semester Students Of Ikip Siliwangi. Indonesian Efl Journal, 4(1), 49-56.

Khairunisa, A., Nadrun, \& Rachmania. (2018). The Correlation Between Students' Grammar Mastery And Writing Skill 
Mundriyah, M., \& Parmawati, A. (2016). Using Think-Pair-Share (Tps) To Improve Students'writing Creativity (A Classroom Action Research In The Second Semester Students Of Stkip Siliwangi Bandung). P2m Stkip Siliwangi, 3(2), 84-91.

Nassaji, H. (2015). Qualitative And Descriptive Research: Data Type Versus Data Analysis. Language Teaching Research, 19(2), 129-132.

Wati, A., \& Nursyaebah. (2017). No Title. An Analysis Of Grammatical Errors In Student' Writing Recount Text, 102. Jawa Timur: English Education Department. 